JOWITA WYCISK

$\stackrel{\circ}{I \mid}$

\title{
TOŻSAMOŚCIOWE WYZWANIA KOBIET SPRAWUJĄCYCH OPIEKĘ NAD DZIECKIEM W ZWIAZZKACH JEDNOPŁCIOWYCH W ŚWIETLE KONCEPCJI VIVIENNE CASS
}

ABSTRACT. Jowita Wycisk, Tożsamościowe wyzwania kobiet sprawujących opiekę nad dzieckiem w zwiq̨zkach jednopłciowych w świetle koncepcji Vivienne Cass [Identity challenges of women taking care of children in same-sex relationships. The Vivienne Cass theory approach] edited by A. Jasielska, M. Obrębska, „'Człowiek i Społeczeństwo" vol. XLV: Oblicza współczesności. Perspektywa psychologiczna [Faces of modernity. A psychological perspective], Poznań 2018, pp. 217-244, Adam Mickiewicz University. Faculty of Social Sciences Press. ISSN 0239-3271.

Development of the contemporary post-industrial society entails the increasing diversity of family life models. People, making individual choices in this field, face new challenges related to identity formation. In the text presented this issue is discussed on the example of women bringing up children in same-sex relationships. The article presents basic information on the same-sex parenting, underlines the importance of the idea of identity integration in psychology and stresses the lack of contiguity between theories of parental identity development and these ones of homosexual and bisexual identity development. An extensive discussion of the Vivienne Cass's theory of sexual orientation identity development is the basis for the approximation of potential discrepancies in the identity system of non-heterosexual women taking parental roles. Two main factors relevant to the processes of identity formation were distinguished: the order of the development of the sexual orientation identity and parental identity (the planned and reconstructed families differ in this regard) and the way of establishing and maintaining the relationship with the child (other challenges are faced by biological and social mothers). In the summary, questions requiring future empirical exploration were notified.

Jowita Wycisk, Instytut Psychologii UAM, ul. Szamarzewskiego 89, 60-568 Poznań, e-mail: jowita. wycisk@amu.edu.pl 


\section{Rodzina ponowoczesna jako źródło wyzwań tożsamościowych}

Z antropologicznego i socjologicznego punktu widzenia rodzina jawi się jako fenomen przyjmujący różne formy w zależności od epoki i lokalnych uwarunkowań historyczno-kulturowych ${ }^{1}$. Współcześnie w kulturze Zachodu (a więc i w państwach postkomunistycznych pozostających pod jej przemożnym wpływem) obserwujemy znaczną różnorodność indywidualnych wyborów w tym zakresie. Obok rodzin nuklearnych istnieją więc rodziny monoparentalne, patchworkowe, rekonstruowane, rodziny typu Double Income No Kids (DINKS, „podwójny dochód, żadnych dzieci”) czy Living Apart Together (LAT, „razem, ale oddzielnie”), rodziny o różnym statusie prawnym (zalegalizowane bądź nie), różnym pochodzeniu dzieci (rodziny naturalne, adopcyjne, zastępcze) i wreszcie - o różnej orientacji seksualnej czy płci osób tworzących relację intymną (rodziny gejowskie i lesbijskie, homorodziny, por. Ukleja, 2011)². Ani obecność dziecka, ani wspólne gospodarstwo domowe czy dychotomiczny podział ról płciowych nie stanowią już elementów definicyjnych rodziny, która na naszych oczach przekształca się ze wspólnoty ekonomicznej i miejsca życia jednostek we wspólnotę o specyficznym znaczeniu dla podmiotowych potrzeb człowieka, związanych głównie z doświadczaniem i odwzajemnianiem intymności, zaufania, troski i wsparcia (Giddens, 2006; Ukleja, 2011).

W dobie wzrastającej autonomii i indywidualizmu ludzie coraz częściej korzystają więc z możliwości samodzielnego decydowania o sposobie życia rodzinnego, choć jednocześnie ponoszą wyłączną odpowiedzialność za konsekwencje swoich decyzji (Ukleja, 2011). Wydaje się prawdopodobne, że z tego powodu życie w rodzinie ponowoczesnej w szczególny sposób pociąga za sobą konieczność uruchamiania intrapsychicznych procesów integracji tożsamości, tak aby była ona w stanie pomieścić zarówno zmienność pełnionych ról, jak i ich ewentualną przeciwstawność. Problematyka ta zostanie w niniejszym tekście zaprezentowana na przykładzie kobiet wychowujących dzieci w związkach jednopłciowych, na podstawie teorii Vivienne Cass.

${ }^{1}$ W tym kontekście termin „rodzina tradycyjna” odnosi się w zasadzie do sposobu życia większości ludzi praktykowanego w danych warunkach i uznanego za normatywny w określonej społeczności (Jabłoński i Ostasz, 2001).

2 Obserwuje się także zmiany w zakresie nazewnictwa nowych form życia rodzinnego mające na celu uniknięcie ich stygmatyzacji (np. określenie „rodzina monoparentalna” zastępuje termin „samotna matka” czy „rodzina niepełna”, por. Burkacka, 2018). 
Zakładam, że istotnym zadaniem rozwojowym związanym z kształtowaniem dojrzałej tożsamości jest dla tych kobiet konieczność integracji (pozornie przeciwstawnych) kategorii tożsamościowych: matki i lesbijki. Na podstawie koncepcji Cass oraz dostępnych doniesień empirycznych wykażę, iż główne obszary potencjalnych wyzwań tożsamościowych mogą być różne dla kobiet pełniących w tych rodzinach role matek biologicznych i społecznych, a ponadto mogą być zależne od historii danej relacji diadycznej i rodziny. Na początek jednak krótko omówię zagadnienie macierzyństwa kobiet nieheteroseksualnych oraz zasygnalizuję podejścia teoretyczne, w których rozważa się rozwój tożsamości rodzicielskiej i tożsamości związanej z orientacją seksualną. To - być może nieco obszerne - wprowadzenie w główną tematykę artykułu ma służyć podkreśleniu konieczności integrowania wiedzy poświęconej problematyce mniejszości seksualnych (pochodzącej głównie z psychologii społecznej i socjologii) z ogólną wiedzą psychologiczną dotyczącą rozwoju tożsamości. W tym kontekście wybór koncepcji Cass jest nieprzypadkowy - choć jest to teoria nienowa, stanowi wciąż aktualny przykład tego typu integracji, możliwy do wykorzystania i rozbudowania przy uwzględnieniu zmieniających się warunków kulturowych.

\section{Macierzyństwo kobiet homo- i biseksualnych}

Macierzyństwo jest w większości kultur doświadczeniem społecznie pożądanym, wysoko cenionym i w wielu państwach - prawnie chronionym. Jest też traktowane jako najbardziej wartościowa forma istnienia dla kobiet (Budrowska, 2000), przynajmniej dopóki podejmowane jest w ramach związku heteroseksualnego (najlepiej - zalegalizowanego, por. DiLapi, 1989). Znacznie mniejszym uznaniem społecznym cieszy się samodzielne sprawowanie opieki nad dzieckiem (Gawlina, 2003), macierzyństwo realizowane przez dwie kobiety pozostające w związku miłosnym jest zaś kulturowo właściwie przemilczane. Wydaje się bowiem, że bycie rodzicem i osobą homo- lub biseksualną postrzegane jest jako trudne do pogodzenia. Nie tylko dlatego, że osoby tej samej płci nie mogą mieć wspólnego biologicznego (genetycznego) potomstwa, lecz także ze względu na to, że homoseksualność w dominującym, rodzimym dyskursie kulturowo-społecznym jest zazwyczaj przeciwstawiana „wartościom rodzinnym”, czy wręcz traktowana jako ich realne zagrożenie (Ukleja, 2014). W interpretacji DiLapi (1989) macierzyństwo lesbijek jest szczególnie zagrażające dla patriarchalnej struktury społeczeństwa, dlatego 
uznaje się je za najbardziej nieodpowiednie i najniżej usytuowane w hierarchii macierzyństwa - w przeciwieństwie do cenionego najwyżej modelu macierzyństwa heteroseksualnego. Mimo to osoby nieheteroseksualne decydują się tworzyć związki jednopłciowe i wspólnie wychowywać dzieci, przy czym rodziny takie funkcjonują nie tylko w krajach Europy Zachodniej, gdzie są rozpoznawane prawnie, lecz także w krajach Europy Wschodniej, w tym w Polsce, gdzie poziom homofobii należy do najbardziej nasilonych w Europie (ILGA Europe, 2017). Obecność rodzin tego typu znajduje odzwierciedlenie w badaniach Mizielińskiej, Abramowicz i Stasińskiej (2014), w których 9\% spośród 2853 nieheteroseksualnych respondentów/ek zadeklarowało, że ma dziecko (191 kobiet i 57 mężczyzn).

Obecnie osoby homoseksualne wychowują dzieci w rodzinach, które przyjmują zróżnicowany kształt (Mizielińska, 2017; Mizielińska, Struzik i Król, 2017; Tomalski, 2007). Zależy to między innymi od:

- płci - kobiety, zarówno ze względu na uwarunkowania biologiczne (ciąża), jak i kulturowe (opieka rodzicielska jako element kulturowego wzorca kobiecości), mają większe szanse na wejście w rolę rodzica i sprawowanie opieki nad dzieckiem w porównaniu z mężczyznami;

- momentu rozwojowego, w którym osoba zakwestionuje swoją (domyślną) heteroseksualność i dokona samookreślenia w innych kategoriach, decydując się na realizację pragnień miłosnych w związku z osobą tej samej płci (od wczesnej adolescencji po późną dorosłość);

- okoliczności, w jakich osoba staje się rodzicem (w związku heteroseksualnym, w związku homoseksualnym, samotnie, jako dawca/dawczyni gamet uczestniczący/a w opiece nad dzieckiem);

- sytuacji osobistej rodzica (rodzicielstwo sprawowane w pojedynkę lub w związku);

- legalnych możliwości realizacji planów rodzicielskich (dostęp par osób tej samej płci do adopcji dzieci lub przysposobienia dziecka partnera/ partnerki, prawo do korzystania z metod wspomaganego rozrodu, takich jak inseminacja, in vitro, surogacja ${ }^{3}$ ).

W anglosaskiej literaturze przedmiotu opisano dość szeroko dwa główne typy rodzin, w których funkcje opiekuńcze pełni para kobiet: rodziny rekonstruowane, gdzie dzieci pochodzą z poprzedniego związku różnopłciowego

${ }^{3}$ W Polsce obecnie wymienione tu formy legalnego podjęcia ról rodzicielskich czy to przez adopcję, czy przez metody wspomaganego rozrodu nie są dostępne dla par tej samej płci, jednak w wielu krajach Unii Europejskiej istnieje możliwość skorzystania z nich, także przez osoby z zagranicy. 
jednej lub obu partnerek, oraz rodziny planowane, gdzie dziecko pojawia się dzięki metodom wspomaganego rozrodu lub adopcji ${ }^{4}$ (Mizielińska i in., 2017; Tasker, 2013). Zazwyczaj w odniesieniu do kobiety, która dziecko rodziła, używa się określenia „matka biologiczna” (biological mother), w stosunku zaś do jej partnerki - „matka społeczna” (social mother, co-mother, step-mother). Takie terminy zostaną też zastosowane w dalszej części tekstu, choć należy pamiętać, że służą one oznaczeniu określonej roli w rodzinie i nie zawsze są sposobem dokonywania samookreślenia przez kobiety (por. Mizielińska, 2017; Mizielińska i in., 2017).

\section{Tożsamość i jej integrująca funkcja}

Zasygnalizowana wcześniej kulturowa przepaść między rodzicielstwem a homoseksualnością znajduje odzwierciedlenie w koncepcjach i badaniach psychologicznych dotyczących tożsamości. Z jednej strony wielu autorów porusza temat procesu „przechodzenia w rodzicielstwo” (transition to parenthood) i kształtowania tożsamości rodzicielskiej (parental identity), z drugiej - wiele miejsca poświęca się rozwojowi tożsamości homoseksualnej czy biseksualnej (homosexual/bisexual identity formation). Obszary te funkcjonują jednak w psychologii rozłącznie i niezależnie.

Dodatkowych trudności nastręcza wielość teorii i badań podejmujących zagadnienie tożsamości jako takiej - pojęcie to jest tyleż popularne, co rozmyte i niejasne (Kubera, 2013), a w licznych opracowaniach pozostaje w ogóle niezdefiniowane. W psychologii termin pojawił się dzięki pracom Erika Eriksona (1950/2000), który tożsamość ego (ego identity) odnosił do spostrzegania własnej osoby w kategoriach niezmienności i ciągłości mimo upływu czasu, jak również spostrzegania faktu, że otoczenie społeczne ową identyczność i ciągłość rozpoznaje i odzwierciedla. W zależności od teoretycznego zaplecza, w pracach poświęconych tożsamości nacisk kładzie się na jej treściowe, procesualne, fenomenologiczne lub motywacyjne aspekty (Batory, Brygoła i Oleś, 2016; Oleś, 2008; Pilarska, 2012). Tym, co mimo wielości podejść wydaje się łączyć różne sposoby myślenia o tożsamości,

${ }^{4}$ Na temat sprawowania opieki nad dzieckiem przez pary mężczyzn wiadomo znacznie mniej. Jakkolwiek pełnią oni funkcje ojcowskie wobec dzieci z poprzednich związków różnopłciowych, to rzadko wiąże się to ze wspólnym zamieszkiwaniem z partnerem i dzieckiem. Geje zostają też ojcami, podejmując decyzję o wspólnym rodzicielstwie z zaprzyjaźnioną kobietą lub parą kobiet, a także przez surogację bądź adopcję - tam, gdzie rozwiązania te są prawnie dopuszczalne (Mizielińska i in., 2017). 
jest - zgodnie z pierwotnym przesłaniem Eriksona - jej integrująca funkcja. „Tożsamość implikuje całościowe odniesienie do siebie i to w fundamentalnej kwestii - określenia kim jestem” (Oleś, 2008, s. 44). Dlatego, jakkolwiek różne role może podejmować jednostka, różne odczucia mogą wypełniać jej pole fenomenologiczne i różne treści może uznawać za najbardziej dla siebie charakterystyczne, tożsamość pozostaje obszarem ich integracji i usensownienia. Wykształcenie spójnego poczucia ja (sens of self) jawi się więc jako istotne zadanie rozwojowe już nie tylko - jak chciał Erikson - okresu adolescencji, lecz także późniejszych etapów życia, zwłaszcza wówczas, gdy człowiek staje w obliczu kryzysów odzwierciedlających zmienność współczesnego świata.

Wynikają z tego istotne ustalenia terminologiczne wprowadzone w dalszej części tekstu. Mówiąc o tych elementach tożsamości, które odnoszą się do rodzicielstwa lub orientacji seksualnej, używać będę - zgodnie z uzusem językowym obecnym w wielu opracowaniach ${ }^{5}$ - wyrażeń „tożsamość rodzicielska” i „tożsamość orientacji seksualnej” (ewentualnie „tożsamość homoseksualna/biseksualna”). Samodzielny termin „tożsamość” zarezerwuję natomiast dla całościowego zbioru właściwości, które wskutek autorefleksji zostają przez podmiot uznane za kluczowe dla dokonania samookreślenia, gwarantującego jednostce poczucie bycia sobą w zmiennej i złożonej rzeczywistości.

\section{Tożsamość rodzicielska}

Zagadnienie tożsamości rodzicielskiej poruszane jest często w kontekście stawania się rodzicem, który to proces jest szeroko dyskutowany w koncepcjach o psychoanalitycznym rodowodzie i opisywany zwłaszcza w odniesieniu do kobiet (Bowlby, 1969; Stern, 1995, Winnicott, 1953). Charakterystyczne jest tu esencjalistyczne ujęcie macierzyństwa jako funkcji zdeterminowanej przede wszystkim biologicznie. Matka postrzegana jest jako główna opiekunka dziecka, a „wystarczająco dobra” jakość opieki i emocjonalnej relacji, jaką z nim tworzy, ma istotny wpływ na jego dobrostan i rozwój psychiczny. Katalizatorem dynamicznych procesów przebiegających w jej psychice są realne zmiany zachodzące w ciele w okresie ciąży, porodu i karmienia piersią. W trakcie ciąży i we wczesnym życiu dziecka

${ }^{5}$ Mam na myśli raczej uzus występujący w tekstach anglojęzycznych (gdzie termin identity przyjmuje często formę liczby mnogiej identities) niż polskich. 
matka wykształca umysłowe reprezentacje: siebie jako rodzica, swojego dziecka oraz ich relacji. Są one jedynie częściowo możliwe do uświadomienia i w dużej mierze opierają się na schematach afektywnego reagowania. Na ich jakość wpływają doświadczenia związane z historią relacji kobiety z własną matką i - w mniejszym stopniu - obiektywne cechy dziecka oraz doświadczenia opieki nad nim przy wsparciu ze strony ojca dziecka i innych osób znaczących (Stern, 1995). Wczesne włączenie funkcji rodzicielskich w obszar tożsamości matki stwarza możliwość ukształtowania prawidłowej więzi z dzieckiem, opartej na zaufaniu i akceptacji. W nurcie tym podnosi się też zagadnienie rozwoju reprezentacji siebie jako ojca u mężczyzn, zwracając uwagę na łagodniejszy i znacznie dłuższy w porównaniu z kobietami proces jej formowania oraz istotny jej komponent, jakim jest wsparcie matki w pełnieniu przez nią funkcji opiekuńczych.

Z kolei w teoriach o rodowodzie socjologicznym, akcentujących w większej mierze procesy konstruowania ról społecznych w negocjacjach z otoczeniam (np. w interakcjonizmie symbolicznym), podkreśla się kwestie dotyczące identyfikowania się z rolą rodzicielską. Rozumie się ją jako kulturowo określony system zgeneralizowanych oczekiwań formułowanych pod adresem jednostki ze względu na miejsce, jakie zajmuje ona w strukturze społecznej (Bakiera, 2013; Burke i Tully, 1977). Role rodzicielskie określane są przez znaczenia i spostrzeżenia kojarzone ze specyficznym statusem powstającym i podtrzymywanym na bazie interakcji z innymi (Inhinger-Tallman, Pasley i Buehler, 1993). W kulturze heteronormatywnej pozostają one w ścisłym związku z rolami płciowymi oraz małżeńskimi, w których zawarte są określone oczekiwania społeczne związane z posiadaniem dziecka i podejmowaniem wobec niego wyznaczonych przepisem roli zobowiązań (Bakiera, 2013). Z takim sposobem ujmowania zagadnienia koresponduje nurt społeczno-poznawczy w psychologii, gdzie duży nacisk kładzie się na spostrzeganie i wartościowanie przez podmiot własnych zachowań i doświadczeń związanych z rolą rodzica. Dla tożsamości rodzicielskiej istotne jest więc to, jak duże znaczenie dla jednostki ma fakt bycia rodzicem, na ile jest ona zadowolona z pełnienia tej roli, jak ocenia własne kompetencje opiekuńczo-wychowawcze i na ile jest skłonna angażować się w czynności rodzicielskie (MacPhee, Benson i Bullock, 1986; Stelter, 2013). W niektórych badaniach pojęcie tożsamości rodzicielskiej sprowadza się wyłącznie do stopnia, w jakim jednostka postrzega rolę rodzica jako istotną dla siebie (Maurer, Pleck i Rane, 2001).

Na koniec warto zaznaczyć, że wątek rozwoju tożsamości w obszarze rodzicielstwa podejmowany jest także (choć rzadko) w badaniach 
wprost inspirowanych koncepcją Eriksona i jego następców (Marcia, 1980). Rodzicielstwo traktowane jest tu jako jedna z dziedzin życia (obok edukacji, życia zawodowego czy relacji intymnych), w której odzwierciedlają się procesy zaangażowania i eksploracji. Harmonijny rozwój tożsamości rodzicielskiej i innych obszarów tożsamości koresponduje z wyższym poziomem dobrostanu matek (Piotrowski, 2018).

Podsumowując, warto podkreślić, że zainteresowanie psychologów tożsamością rodzicielską wydaje się niewspółmiernie małe zarówno wobec czasu, jaki większość ludzi poświęca wypełnianiu ról rodzicielskich w swoim życiu, jak i rangi, jaką psychologia nadaje znaczeniu wychowania i relacji z rodzicami dla psychicznego rozwoju człowieka. Dociekliwość, z jaką podejmowana jest problematyka rodzinnych uwarunkowań prawidłowego rozwoju dzieci, zdecydowanie przyćmiewa refleksję nad znaczeniem rodzicielstwa dla funkcjonowania samych rodziców (Bakiera, 2013). Ponadto rodzicielstwo postrzega się jako wyraźnie powiązane z heteronormatywnymi wartościami, a także - często - esencjalistycznymi założeniami dotyczącymi biologicznych dyspozycji mężczyzn i kobiet do podejmowania określonych ról; na gruncie psychologii pozostaje więc ono domeną heteroseksualnej rodziny nuklearnej.

\section{Tożsamość orientacji seksualnej}

W porównaniu z omówioną wyżej tożsamością rodzicielską zagadnienie tożsamości związanej z ukierunkowaniem pragnień seksualnych i miłosnych na gruncie psychologii doczekało się znacznie większej liczby omówień naukowych ${ }^{6}$. Być może przyczyną zainteresowania tym obszarem tożsamości jest jego nieoczywistość oraz nowość, wynikająca ze zmiany w postrzeganiu statusu nieheteroseksualności w ciągu ostatnich kilkudziesięciu lat.

Już Erikson, kreśląc ścieżkę rozwoju człowieka, kładł nacisk na rolę środowiska społecznego w wysiłkach podejmowanych przez jednostkę stającą przed wyzwaniem udzielenia odpowiedzi na pytanie „Kim jestem?”.

${ }^{6}$ Dość przywołać liczbę znalezionych rekordów dla wybranych wyrażeń w bazach PsycINFO i PsycARTICLES: „tożsamość rodzicielska” (parental identity) - 107 wyników, „tożsamość macierzyńska” (maternal identity, mother identity), odpowiednio: 155 i 26 wyników, „tożsamość ojcowska” (paternal identity, father identity), odpowiednio: 48 i 41 wyników. Dla porównania, liczba wyników uzyskanych dla wyrażeń „tożsamość homoseksualna” (homosexual identity), „tożsamość gejowska” (gay identity), „tożsamość lesbijska” (lesbian identity) i „tożsamość biseksualna” (bisexual identity) to, odpowiednio: 248, 573, 379 i 406. 
W przypadku osób nieheteroseksualnych znaczenie grupy odniesienia jest szczególne, a trudność zidentyfikowania się z dominującą kulturą może skutkować specyficzną trajektorią rozwoju (Coleman, 1982; Glover, Galliher i Lamere, 2009). Zagadnienie to podejmują liczne koncepcje rozwoju tożsamości homoseksualnej i biseksualnej, formułowane od późnych lat sześćdziesiątych XX w. na gruncie psychologii i socjologii.

W próbie ich podsumowania i uporządkowania Michele Eliason i Robert Schope (2006) odwołują się do rozróżnienia paradygmatów esencjalistycznego i konstrukcjonistycznego, zakreślając wynikające z nich konsekwencje dla sposobu rozumienia kategorii tożsamości płciowej i seksualnej. Koncepcje esencjalistyczne zakładają, że kategorie te odnoszą się do bytów zdeterminowanych biologicznie (ewentualnie kształtujących się w bardzo wczesnym dzieciństwie), danych raz na zawsze, jasno określonych i stabilnych w czasie. Rozwój homo- lub biseksualnej tożsamości polega więc na „odkrywaniu” przez podmiot własnej „natury”, co przebiega według linearnego schematu obejmującego kolejne zadania rozwojowe i w literaturze przedmiotu często jest określane mianem coming outu (por. Cass, 2015; Coleman, 1982). W koncepcjach tego typu różnica między orientacją homoseksualną i tożsamością homoseksualną jest bardzo subtelna, gdyż ta druga jest zaledwie odzwierciedleniem tej pierwszej.

Z kolei przedstawiciele nurtu konstrukcjonistycznego w ogóle podważają zasadność stosowania pojęcia orientacji seksualnej jako stałej właściwości człowieka, powołując się na liczne przykłady zmian zachodzących w toku życia jednostek zarówno w zakresie zachowań seksualnych, jak i sposobów dokonywania przez ludzi samookreślenia (Bojarska, 2008). Tożsamość płciową i seksualność człowieka traktują jako wytworzoną społecznie przez miejsce, czas i kulturę, w której żyje jednostka. Wraz ze wzrostem indywidualizmu naszej kultury i społecznym ujawnianiem się kolejnych grup wykluczonych ze względu na seksualność i identyfikację płciową kafeteria tożsamościowych etykiet odzwierciedlających tę sferę życia sukcesywnie się powiększa. Skrajne stanowisko prezentują teoretycy queer, dla których tożsamość staje się zmienna, płynna, ,performatywna”, konstruowana w toku nieustannych interakcji, odgrywana i uwikłana w system stosunków władzy, traci więc całkowicie swoje pierwotne znaczenie (por. Butler, 1990/2008).

W przestrzeni rozciągającej się między tymi dwoma podejściami plasuje się wiele modeli teoretycznych, które - niezależnie od szczegółowych rozróżnień - opisują proces dokonywania przez jednostkę samookreślenia w kategoriach nieheteroseksualnych. U źródeł tego procesu leży indywidualne doświadczenie poczucia odmienności w sferze płci czy seksualności, 
jego ostatecznym zwieńczeniem jest zaś akceptacja i trwała integracja nieheteroseksualności w obszar tożsamości jednostki (Eliason i Schope, 2006). Środowisko społeczne odgrywa tu znaczącą rolę, gdyż to wobec niego i przed nim jednostka dokonuje samookreślenia. Dzieje się to zarówno na poziomie symbolicznym - wobec zastanych norm i wartości, jak i na poziomie realnym, relacyjnym - wobec konkretnych osób (rodziny, rówieśników, bliskich).

Jedną z wczesnych koncepcji opisujących ten proces jest propozycja Vivienne Cass ${ }^{7}$ rozwinięta i zweryfikowana na przełomie lat siedemdziesiątych i osiemdziesiątych XX w. Propozycja ta początkowo nosiła miano teorii formowania tożsamości homoseksualnej (Theory of Homosexual Identity Formation), choć z biegiem czasu autorka zaczęła używać określenia teoria formowania gejowskiej i lesbijskiej tożsamości (Theory of Lesbian and Gay Identity Formation), czy wreszcie - teoria formowania tożsamości orientacji seksualnej (Theory of Sexual Orientation Identity Formation). Jakkolwiek egzotycznie brzmi ostatnie wyrażenie w języku polskim, pojęcie „tożsamość orientacji seksualnej” najtrafniej odzwierciedla ten obszar tożsamości, którego rozwój jest przedmiotem niniejszych rozważań. Uzasadnienie wyboru wspomnianego terminu, a także samej koncepcji i jej szczegółowych teoretycznych założeń zostanie omówione w następnym paragrafie.

\section{Vivienne Cass koncepcja formowania tożsamości orientacji seksualnej}

Koncepcja Cass (1979; 1984a; 1984b; 1996) jest nie tylko propozycją zweryfikowaną empirycznie i bodaj najczęściej cytowaną w omawianym kontekście. Po trzydziestu sześciu latach od opublikowania pierwszego artykułu doczekała się także ponownego autorskiego przeglądu i omówienia, uwzględniającego zmiany kulturowe, jakie zaszły od jej pierwszego wydania drukiem (Cass, 2015). W odróżnieniu od licznych modeli, które jak grzyby po deszczu zaczęły się pojawiać w czasopismach z zakresu nauk społecznych w latach siedemdziesiątych i osiemdziesiątych XX w., propozycja ta bazuje na jasno określonych założeniach teoretycznych, uwzględnia zastaną wiedzę z zakresu psychologii i socjologii, definiuje podstawowe pojęcia i w swoich głównych tezach nie traci na aktualności.

${ }^{7}$ Cass, związana wcześniej z Curtin University w Perth w zachodniej Australii, jest obecnie emerytowaną psycholożką kliniczną i seksuolożką, autorką licznych publikacji z zakresu ludzkiej seksualności (informacje ze strony: http://www.brightfire.com.au/ dr-vivienne-cass/brief-summary/). 
Podstawowe założenia epistemologiczne swojej koncepcji australijska klinicystka i badaczka (2015) osadza w dwóch nurtach: psychologii społeczno-konstrukcjonistycznej (social constructonist psychology) i psychologii wiedzy (psychology of knowledge). Zgodnie z duchem pierwszego z nich autorka podkreśla znaczenie środowiska społecznego i procesu socjalizacji w przebiegu rozwoju człowieka. Tożsamość orientacji seksualnej traktowana jest raczej jako specyficzna kulturowo rzeczywistość psychologiczna aniżeli obiektywna, uniwersalna właściwość zakorzeniona w wewnętrznych, biologicznych i psychologicznych mechanizmach (co z kolei cechuje podejście esencjalistyczne). W odróżnieniu od radykalnych ujęć konstrukcjonizmu socjologicznego czy interakcjonizmu symbolicznego Cass nie neguje jednak istnienia właściwości biologicznych i psychologicznych ani nie odbiera im znaczenia w konstruowaniu tożsamości. Autorka wskazuje, że tożsamość wykształca się w toku wzajemnych, dynamicznych oddziaływań (Dynamic Interaction Process) pomiędzy czynnikami biologicznymi i psychologicznymi a środowiskiem zewnętrznym. Zachodzą one w relacjach interpersonalnych, w wielokrotnych wymianach społecznych i mają charakter mniej lub bardziej jawnych negocjacji obejmujących: spostrzeżenia dotyczące samego siebie, ekspresje językowe, przyswojone pojęcia, doświadczenia emocjonalne i podejmowane działania. Co ważne, jednostka jest aktywnym uczestnikiem opisywanych procesów, a nie jedynie spadkobiercą biologicznych predyspozycji czy kulturowych nakazów - autorka wyraźnie podkreśla rolę podmiotowego sprawstwa.

Psychologia wiedzy stanowi drugi obszar teoretyczny, na którym bazuje Cass. Autorka odwołuje się do pojęcia psychologii indygenicznej (indigenous psychology), która odnosi się do sieci wiedzy psychologicznej zawierającej informacje na temat tego, co w danym środowisku społeczno-kulturowym i momencie historycznym jest traktowane jako prawdziwe w odniesieniu do natury ludzkiej. Wiedza na temat seksualności, wchodząca w zakres tak rozumianej psychologii, współcześnie podlega intensywnym zmianom, jest niejednolita i obejmuje zestaw stosunkowo młodych pojęć, takich jak: „heteroseksualność”, „homoseksualność”, „orientacja seksualna”, coming out, „tożsamość seksualna”, „tożsamość gejowska/lesbijska”. Wiedza ta jest przyswajana w toku socjalizacji i - na poziomie indywidualnym - przetwarzana na jedyną w swoim rodzaju wiedzę osobistą, czy też indywidualną sieć znaczeniową, która przyjmuje postać poznawczo-emocjonalnych schematów służących jako ramy organizacji i interpretacji informacji.

Formowanie tożsamości orientacji seksualnej Cass rozumie jako dynamiczny proces interakcji między jednostką a otoczeniem, za pośrednictwem 
którego „ludzie dokonują przełożenia zakorzenionego w zachodniej psychologii indygenicznej, powszechnego rozumienia orientacji seksualnej, tożsamości, homoseksualności i kulturowej narracji na temat «coming outu» w osobisty system wiedzy, zachowań, przekonań i doznań, formujących wewnętrzne doświadczanie tożsamości” (Cass, 2015, s. 40). Tożsamość orientacji seksualnej w ujęciu Cass oznacza względnie stały sposób postrzegania i doświadczania siebie jako „lesbijki”, „geja” czy „osoby biseksualnej”, który „,wyrasta (jest konstruowany) z trwałych i stabilnych elementów i procesów zachodzących w obrębie interakcji między jednostkami a ich otoczeniem" (Cass, 1996, s. 231). Podtrzymywany w umyśle i poddawany refleksji poznawczy wizerunek siebie jako osoby nieheteroseksualnej autorka uznaje za obiektywny aspekt tożsamości, podczas gdy doświadczeniowe poczucie „bycia gejem” czy „bycia lesbijką” - za jej aspekt subiektywny (Cass, 1984b; 2015). Używając określenia „tożsamość orientacji seksualnej”, Cass odróżnia je od znacznie szerszego pojęcia „tożsamości seksualnej”, oznaczającego ogólną koncepcję siebie jako istoty seksualnej.

Cass rozróżnia ponadto trzy konstrukty odnoszące się do zagadnienia tożsamości:

- pojęcie ja (self-concept), obejmujące wszystkie podtrzymywane przez jednostkę spostrzeżenia, treści i postawy odnoszące się do siebie;

- tożsamość typologiczną (typological identity), stanowiącą zorganizowany zbiór obrazów siebie i powiązanych z nimi uczuć, dotyczących określonej kategorii społecznej. Kategorie społeczne są z kolei rozumiane jako konstrukcje umożliwiające dokonywanie klasyfikacji ludzi na podstawie wybranych atrybutów (takich jak wiek, rasa, zawód, a także orientacja seksualna);

- tożsamość złożoną (composite identity), oznaczającą globalny obraz i całościowe poczucie ja, które obejmuje i integruje wszystkie tożsamości typologiczne danej osoby (Cass, 1984b; 2015).

Rozwój tożsamości orientacji seksualnej można więc rozpatrywać jako z początku - włączanie pojedynczych treści i spostrzeżeń odnoszących się do pragnień czy zachowań o charakterze seksualnym w obszar pojęcia ja, następnie nadawanie tym treściom znaczenia i wytwarzanie na ich podstawie

${ }^{8}$ Worthington, Savoy, Dillon i Vernaglia (2002) proponują, by w ramach pojęcia tożsamości seksualnej uwzględniać, obok tożsamości orientacji seksualnej: świadomość własnych potrzeb seksualnych, preferowanych aktywności seksualnych, preferowanych cech partnera i sposobów ekspresji seksualnej oraz osobistych wartości przypisywanych seksualności. 
tożsamości typologicznej (zgodnie z zainkorporowanymi z kultury kategoriami orientacji seksualnej) i - w końcu - integrowanie tejże z innymi kategoriami w tożsamość złożoną.

Czynnikami popychającymi jednostkę do dokonywania tych zmian są dwa główne motywy szeroko opisane w literaturze psychologicznej: motyw spójności i motyw samooceny. Spostrzeżenie własnego zainteresowania osobą tej samej płci - o ile jest niezgodne z posiadanym, heteronormatywnym obrazem siebie - prowadzi do aktywizacji obu motywów. Po pierwsze, wywołuje brak spójności w obszarze ja, wytwarza dysonans poznawczy i nieprzyjemne napięcie, które motywuje do podejmowania różnorodnych strategii zaradczych. Po drugie, wzbudza negatywne emocje względem samego siebie, gdyż zachowanie czy pragnienie homoseksualne oceniane jest jako niepożądane (przez siebie lub innych), co stanowi zagrożenie dla samooceny (Cass, 1984b; 2015).

Formułując szczegółowe założenia swojej koncepcji, Cass (1979; 1984b; 2015) nawiązuje do teorii zgodności interpersonalnej (Interpersonal Congruency Theory) autorstwa Paula Secorda i Carla Backmana (1961; por. też Backman, 1988) i zapożycza od nich pojęcie interpersonalnej matrycy czy też systemu (interpersonal matrix/system). Składają się na nie:

- indywidualny sposób postrzegania przez podmiot określonej właściwości, stanowiącej pewien aspekt jej pojęcia ja (self-concept) - w tym przypadku własnej orientacji seksualnej ( $\mathrm{J}$ - od ja);

- subiektywna percepcja i ocena własnych zachowań związanych z tym aspektem (w interpretacji Cass chodzi tu nie tylko o zachowania, lecz także o pragnienia, fantazje czy zauroczenia o charakterze homoseksualnym; $\mathrm{Z}$ - od zachowanie);

- indywidualny sposób postrzegania zachowań (ale i uczuć czy przekonań) innych osób w odniesieniu do tej właściwości, czyli to, jak - w percepcji podmiotu - inni postrzegają jej orientację seksualną (I - od inni).

Matryca ta stanowi pole dynamicznych zmian rozwojowych. Zachodzą one od momentu, w którym jednostka wychowana w heteronormatywnej kulturze spostrzega u siebie oznaki erotycznego zainteresowania osobą tej samej płci, co prowadzi do naruszenia spójności matrycy, do czasu rozpoznania i akceptacji własnej homoseksualności przez siebie i przez innych, co skutkuje ponownym uzyskaniem zgodności między wszystkimi elementami systemu. Jakkolwiek proces ten zachodzi na poziomie indywidualnym, w obszarze spostrzeżeń i wyobrażeń jednostki na swój temat, istotną rolę odgrywa tu również to, jak interpretuje ona postawy i działania innych. Ów trzeci komponent matrycy pozostaje pod wpływem 
bezpośrednich interakcji jednostki ze środowiskiem społecznym. Jego specyfika polega na tym, że angażuje zarówno świat osobistych znaczeń, jakie jednostka nadaje obserwowanym zachowaniom innych ludzi, jak i zewnętrzny, względnie zobiektywizowany świat relacji interpersonalnych, w których pozostaje. Zgodnie z myślą Secorda i Backmana struktura społeczna - z jej kulturowymi, normatywnymi i instytucjonalnymi siłami - kształtuje jakość i częstość tych relacji, sytuuje jednostkę w różnorodnych rolach społecznych i wpływa na to, jak zachowują się wobec niej znaczący inni, ma więc istotny wpływ na zachowanie i kształtowanie osobistej koncepcji ja. Z drugiej strony zmiany zachodzące na poziomie indywidualnym mogą prowadzić podmiot do aktywnego działania w kierunku modyfikacji relacji interpersonalnych, co zwrotnie może sprzyjać wprowadzaniu dalszych zmian w obrębie wewnętrznej matrycy, a na poziomie społecznym, w dłuższej perspektywie czasowej, prowadzić do transformacji struktury społecznej.

Cass wyodrębnia kolejne fazy rozwoju tożsamości orientacji seksualnej na podstawie tego, czy jednostka interpretuje własne zachowania i pragnienia w kategoriach homoseksualności oraz czy uznaje za trwały element tożsamości orientację homoseksualną i przynależność do określonej mniejszości, której ocena społeczna jest niejednolita i często bywa negatywna. Obszernie omawia też złożone strategie obronnego redukowania rozbieżności wewnątrz matrycy i utrzymywania wysokiej samooceny (ich prezentacja znacznie przekroczyłaby ramy niniejszego artykułu). W koncepcji tej wraz z rozwojem poszerza się zakres samoakceptacji jednostki: najpierw dotyczy on pojedynczych homoseksualnych doświadczeń, następnie samookreślenia orientacji seksualnej i - co za tym idzie społecznej grupy odniesienia, by w końcu objąć to, jak widzą jednostkę inni. Poszczególne stadia, towarzyszące im zmiany i ich tożsamościowe efekty przedstawia tabela ${ }^{9}$.

${ }^{9}$ Warto podkreślić, że rozwój tożsamości orientacji seksualnej został przez Cass po raz pierwszy opisany w kontekście kultury anglosaskiej lat siedemdziesiątych XX w., kiedy heteroseksizm był zjawiskiem o wiele szerzej rozpowszechnionym niż obecnie. Niezależnie od zmian, które dokonały się od tego czasu, propozycja teoretyczna Cass pozostaje aktualna - odnosi się bowiem do jakości procesów poznawczych (zgodności lub jej braku), które wydają się niezależne od treści przekonań rozpowszechnionych w danym momencie historycznym i danej kulturze. Cass sugeruje, że większa akceptacja społeczna osób LGB w dniu dzisiejszym może odzwierciedlać się w mniejszej intensywności emocji negatywnych przeżywanych przez jednostkę zwłaszcza w początkowych stadiach rozwoju i w częstszych wyborach pozytywnych ścieżek rozwojowych. 


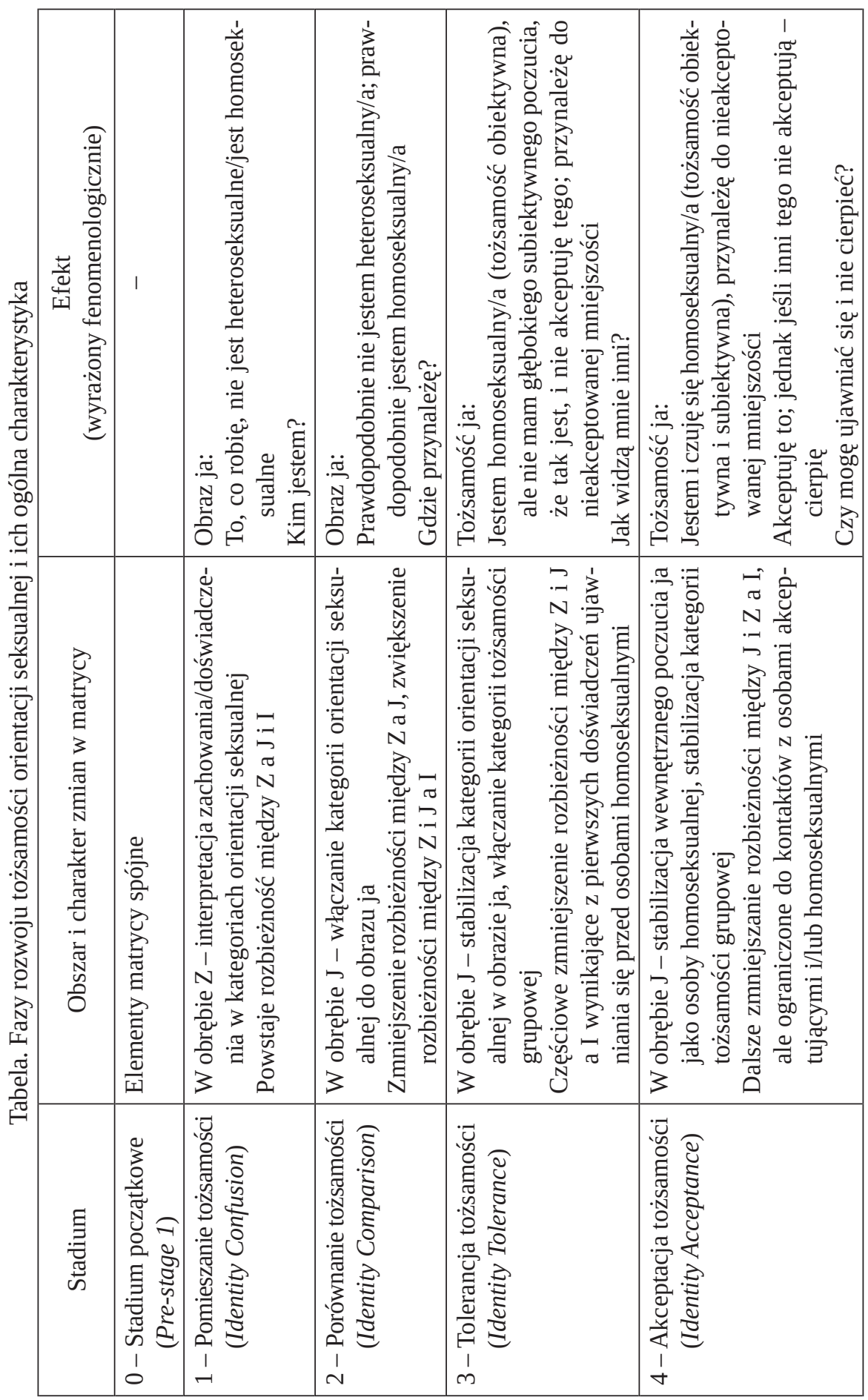




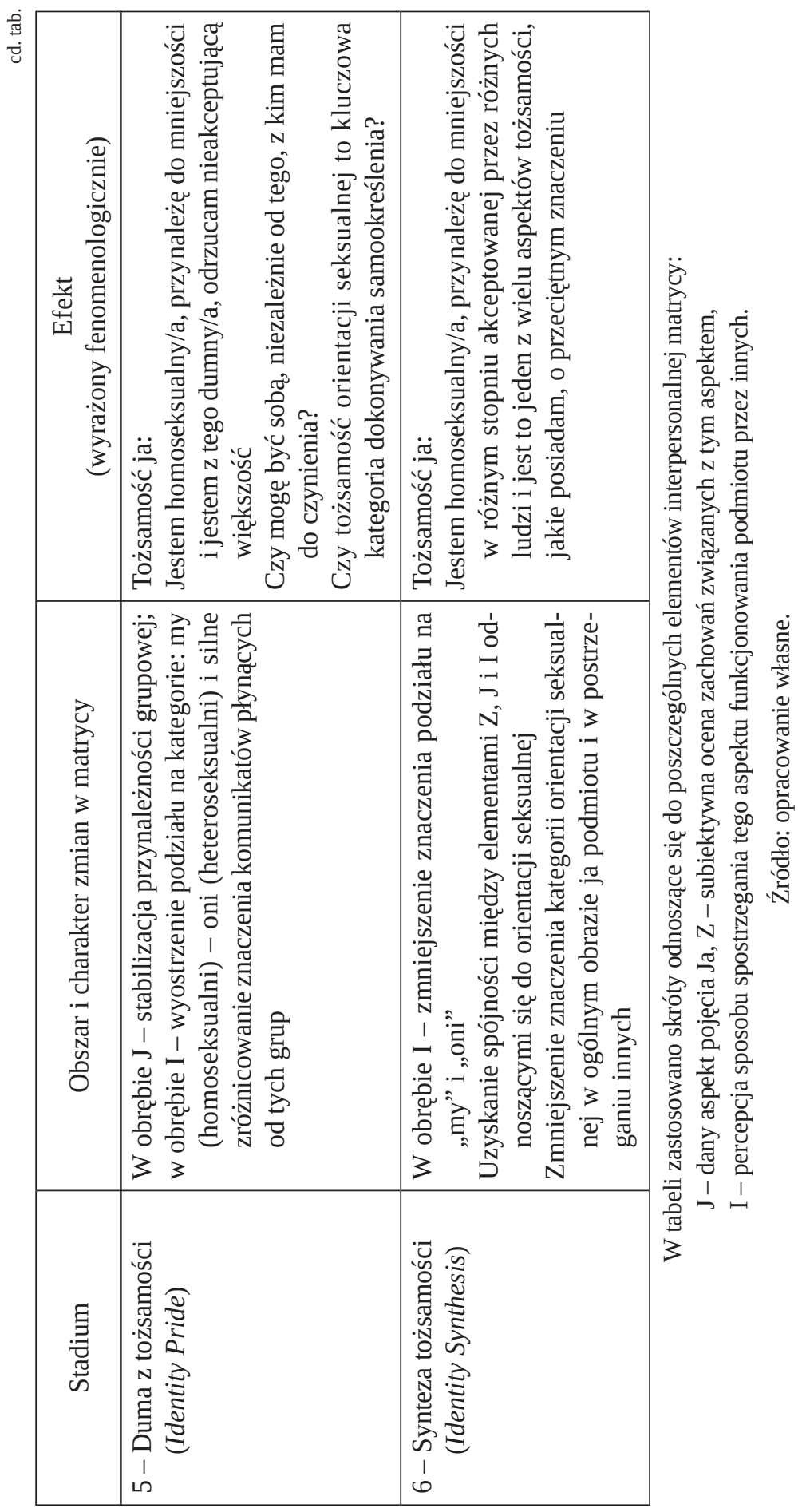


Jakkolwiek Cass w swoim modelu nie dokonuje wprost rozróżnienia na tożsamość osobistą i społeczną ${ }^{10}$, to wyraźnie wskazuje, iż rozwój w obszarze identyfikacji i integracji doświadczeń osobistych wyprzedza budowanie poczucia przynależności do grupy (co jest zgodne z późniejszą, alternatywną propozycją McCarn i Fassinger (1996) rozwoju tożsamości lesbijskiej). Ze względu na przypisanie istotnej roli procesom odzwierciedleń społecznych zachodzących w interakcjach szczególnego znaczenia w konstruowaniu tożsamości nabierają akty ujawniania innym informacji o swojej orientacji seksualnej i doświadczenia zebrane w ten sposób. To, przed kim jednostka się ujawnia (czy są to osoby homoseksualne czy heteroseksualne), z jakimi reakcjami się spotyka w sytuacji ujawnienia i jaką rangę nadaje informacjom zwrotnym, odgrywa istotną rolę w ostatecznym uformowaniu i zaakceptowaniu tożsamości orientacji seksualnej innej niż heteroseksualna.

Nie ulega wątpliwości, że w koncepcję Cass wpisane jest założenie o mniejszościowym statusie tożsamości orientacji seksualnej. W kulturze, w której domniemana trajektoria rozwoju ma charakter heteroseksualny, orientacja seksualna wymaga włączania w obszar tożsamości właśnie dlatego, że jest mniejszościowa. Kategoria ta musi zaistnieć w świadomości podmiotu, wyłania się więc w sposób nader wyrazisty i zwykle związany z (przynajmniej) przejściowymi emocjonalnymi perturbacjami, co - z założenia - nie dzieje się w przebiegu rozwoju heteronormatywnego. Jak twierdzi autorka, konieczność zmian w interpersonalnej matrycy i ponownego ustanowienia zgodności między jej elementami stanowi następstwo każdego nowego doświadczenia, niespójnego z dotychczasowym sposobem myślenia o sobie. Kwestia braku kulturowego rozpoznania określonej tożsamości i braku społecznego na nią przyzwolenia sprawia, że jest to proces złożony i długotrwały.

\section{Wyzwania tożsamościowe nieheteroseksualnych matek w świetle koncepcji Cass}

Bycie matką to kategoria tożsamości typologicznej, którą także można rozpatrywać, odwołując się do przedłożonej koncepcji. Pierwszym elementem interpersonalnej matrycy byłoby więc uznanie siebie za matkę na poziomie samoopisu i włączenie w obraz ja pewnej indywidualnie zinterpretowanej roli społecznej (J); drugim - zachowania i doświadczenia poddawane podmiotowej

${ }^{10}$ Rozróżnienie to postulują w swojej koncepcji McCarn i Fassinger (1996), choć - jak same podkreślają - rozwój tożsamości osobistej i grupowej pozostaje ze sobą w ścisłym związku. 
interpretacji w kategoriach rodzicielstwa, głównie zatem te z kręgu sprawowania opieki i wychowania dziecka (choć być może także samo pragnienie posiadania dziecka (Z)); trzecim zaś - interpretacje odniesień innych osób w stosunku do tych zachowań i - ogólnie - do danej osoby jako matki (I).

Można zakładać, że proces rozwoju tożsamości macierzyńskiej u kobiet pozostających w związku z mężczyzną - przynajmniej w sytuacji, gdy stają się matkami zgodnie ze swoim pragnieniem - przebiega łagodniej niż opisany wyżej rozwój tożsamości orientacji seksualnej. Nie oznacza to, że kształtowanie tożsamości rodzicielskiej zawsze przebiega harmonijnie ${ }^{11}$. Istnieje wiele wymogów kulturowo-społecznych, internalizowanych w toku socjalizacji, dotyczących bycia (wystarczająco) dobrą matką. Dążenie do sprostania określonemu wizerunkowi tej roli, przy jednoczesnym łączeniu jej z innymi obszarami tożsamości, może być źródłem dynamicznych procesów rozwojowych (Miluska, 1996). Wydaje się jednak, że w przypadku tożsamości macierzyńskiej obszarem ewentualnych trudności jest najczęściej to, jak kobieta ocenia siebie (i jest oceniana) jako matka. Jest to zatem głównie kwestia oceny własnych kompetencji, nie zaś samego faktu bycia matką. Macierzyństwo w związku heteroseksualnym - jako doświadczenie większościowe, przewidywalne, oparte na dostępnych wzorcach kulturowych i społecznie cenione - nobilituje kobietę, dzięki czemu dość płynnie może zostać włączone w obszar tożsamości. Jak natomiast dynamika ta mogłaby wyglądać w przypadku matek homo- i biseksualnych?

Pierwszym czynnikiem, który może determinować ten proces, jest kolejność formowania i integrowania obu kategorii tożsamościowych. Kobieta może podjąć decyzję o macierzyństwie jako osoba, która wcześniej zaakceptowała i włączyła homoseksualność w obszar własnej tożsamości, tak jak ma to miejsce w planowanych rodzinach lesbijek. Może też jednak najpierw założyć rodzinę opartą na związku z mężczyzną, podjąć w niej rolę matki i dopiero wówczas rozwinąć nieheteroseksualną tożsamość. W tym drugim przypadku będzie to ściśle związane z poważną zmianą w zakresie życia rodzinnego - rozstaniem z ojcem dziecka oraz wejściem w związek z kobietą. Wydaje się prawdopodobne, że wówczas proces integrowania kategorii orientacji seksualnej i bycia matką będzie stanowił swoiste wyzwanie rozwojowe.

Drugim czynnikiem znaczącym dla rozwoju tego typu tożsamości byłaby pozycja zajmowana wobec dziecka i charakter więzi, którą kobieta z nim

\footnotetext{
${ }^{11}$ Podjęcie roli matki w wieku kilkunastu lat, przed ukończeniem procesu edukacji (macierzyństwo niepunktualne), bycie matką dziecka z niepełnosprawnością lub inne okoliczności mogą implikować specyficzne trudności w tym procesie.
} 
tworzy. W przypadku matek biologicznych pozycja ta jest jasno określona i uregulowana prawnie, ma też przynajmniej częściowe oparcie w kulturowych wzorcach i oczekiwaniach społecznych związanych z biologiczną podstawą więzi. Dla partnerek matek biologicznych kwestia ta jest znacznie bardziej złożona w obu typach rodzin (i można sądzić, że w każdej wygląda nieco inaczej). Każdorazowo kobiety te dokonują samookreślenia bez oparcia w gotowych wzorcach, niekiedy identyfikując się z rolą rodzicielską i nawiązując silną więź z dzieckiem (zwłaszcza w przypadku rodzin planowanych, w których obie kobiety od narodzin sprawują opiekę nad dzieckiem), kiedy indziej zaś wytwarzając rodzaj alternatywnej roli zajmowanej wobec dziecka, definiowanej w negocjacjach z partnerką (i dzieckiem) i funkcjonując w roli rodzica zastępczego czy też dodatkowej opiekunki dziecka (w szczególności w rodzinach rekonstruowanych, gdzie dzieci pozostają pod formalną opieką obojga rodziców biologicznych, a budowanie przez nie więzi z partnerką matki rozpoczyna się już w pewnym wieku).

Poniżej, dokonując znacznego uogólnienia, omówię główne obszary potencjalnych przekształceń w obrębie tożsamości u kobiet pozostających w związkach jednopłciowych i wychowujących wspólnie dzieci w rodzinach planowanych i rekonstruowanych.

\section{Rodziny planowane}

Można zakładać, że w rodzinach planowanych rozwój tożsamości orientacji seksualnej wyprzedza rozwój tożsamości rodzicielskiej. Kobiety, planując powiększenie rodziny, są świadome własnej homoseksualności, mają za sobą pewien etap wspólnego życia w związku i przynajmniej jednostkowe doświadczenia ujawniania się przed innymi. Jest więc wysoce prawdopodobne, że ich nieheteroseksualny obraz siebie jest przez nie zaakceptowany i zintegrowany na tyle, by móc stawić czoła nowemu pragnieniu, jakim jest budowanie nieheteronormatywnej rodziny z dzieckiem/dziećmi.

Decydując się na dziecko, kobiety rozstrzygają wiele kwestii związanych z tym, w jakich okolicznościach podejmą opiekę nad nim (adopcja versus metody sztucznego wspomagania rozrodu ${ }^{12}$ ), jeśli któraś z partnerek będzie rodzić, to która, a także czy w wychowaniu będzie uczestniczył ojciec i - jeśli

${ }^{12}$ W Polsce obecnie obie te formy, nawet jeśli praktykowane (np. w procesie samodzielnego przysposobienia dziecka przez jedną z kobiet lub w ramach procedur wspomaganego rozrodu realizowanych za granicą), nie prowadzą do rozpoznania matki społecznej jako rodzica/prawnego opiekuna dziecka. 
tak - to na jakich warunkach (Bos, 2013). Ponadto, będąc świadome wyzwań i potencjalnych zagrożeń związanych ze stygmatyzacją dziecka i ich rodziny, kobiety rozważają różne możliwości przeciwdziałania ewentualnym trudnościom i zabezpieczenia interesów dziecka oraz tej z kobiet, która nie jest rozpoznawana jako jego prawny opiekun (Mizielińska, 2017). Proces decydowania się na dziecko jest więc o wiele bardziej złożony, czasochłonny i wymagający refleksji niż w przeciętnym związku heteroseksualnym, co sprawia, że pary kobiet stosunkowo późno (zwykle między 30. a 40. rokiem życia) podejmują role rodzicielskie (Morris, Balsam i Rothblum, 2002; Bos, 2013). Można zaryzykować twierdzenie, że ów dość rozbudowany etap planowania wspólnego rodzicielstwa jest też wstępnym etapem rozwoju tożsamości macierzyńskiej, w którym pragnienie bycia rodzicem i starania podejmowane w tym celu (Z) są włączane do ogólnego obrazu ja (J) oraz sukcesywnie integrowane z innymi tożsamościami typologicznymi, w tym z tożsamością orientacji seksualnej. Wydaje się, że sygnalizowana wcześniej kulturowa rozbieżność między byciem rodzicem a byciem osobą homo- lub biseksualną musi zostać w tym procesie przekroczona - w przeciwnym razie nie sposób byłoby podjąć decyzję o rodzicielstwie $^{13}$. Rola matki, którą realizują kobiety w tego typu związkach, jest od początku alternatywna w stosunku do roli matki pojmowanej tradycyjnie właśnie ze względu na fakt, że nie jest heteronormatywna. Proces rozwoju tożsamości rodzicielskiej odbywa się zatem na bazie uformowanej wcześniej tożsamości orientacji seksualnej i jest od początku tworzeniem tożsamości matki - lesbijki czy też matki nieheteronormatywnej.

Zasygnalizowany tu proces wymaga także uwzględnienia trzeciego aspektu matrycy, jakim jest percepcja tego, jak inni postrzegają i oceniają fakt starania się o dziecko, a następnie wspólne wychowywanie go przez parę kobiet (I). Istotnym elementem procesu formowania tożsamości matki nieheteronormatywnej jest konfrontacja powszechnych (i nierzadko zinternalizowanych) stereotypów i uprzedzeń związanych z rodzicielstwem osób tej samej płci, prowadząca do refleksyjnego opracowania własnej postawy wobec niego. Co zaś się tyczy ocen innych osób - bywają one zróżnicowane i niekiedy zaskakujące, jak np. przejawy dezaprobaty ze strony przedstawicieli własnej mniejszości (Danna, 2011), ale i życzliwości skutkującej ociepleniem stosunków ze strony rodzin pochodzenia kobiet (Mizielińska, 2017;

${ }^{13}$ Niemożność przekroczenia rozbieżności w tym zakresie prawdopodobnie jest dla wielu osób powodem nieposiadania dziecka. W badaniu Mizielińskiej, Abramowicz i Stasińskiej (2014) 19\% spośród 2147 badanych osób LGBT stwierdziło, że nie chce mieć dzieci, ponieważ jest to niemożliwe w relacji z osobą tej samej płci, a 11\% uznało, że powstrzymują je obawy związane z dyskryminacją społeczną i brak prawnej możliwości adopcji. 
Mizielińska i in., 2017). Wydaje się, że doświadczenie opieki nad dzieckiem jest tym, które zmniejsza psychologiczny dystans pomiędzy heteronormatywną większością i nieheteronormatywną mniejszością - być może ze względu na nadrzędną wartość, jaką stanowi życie i rozwój dziecka oraz niezależną od płci opiekunów konieczność otoczenia go troską. Rozpoznanie tej wartości może dla wielu kobiet być istotnym elementem kształtowania obrazu siebie. Dodatkowym źródłem uznania i potwierdzenia tożsamości jest kontakt z innymi parami żyjącymi w podobnym modelu rodzinnym.

Należy też zwrócić uwagę, że pozycja matki biologicznej i społecznej $\mathrm{w}$ tak powstałej rodzinie nie jest porównywalna, co wiąże się z wysokim wartościowaniem więzi biologicznych i znajduje odzwierciedlenie w potencjalnie zróżnicowanym przebiegu procesów rozwoju tożsamości. Matki biologiczne mogą swobodnie korzystać z gotowych i bogatych skryptów kulturowych, przekształcając je w sposób najbardziej dla siebie dogodny, a status „tej, która rodziła” wyznacza ich szczególne miejsce w opiece nad dzieckiem i w rodzinie. W przypadku matek społecznych ich rola nie jest prawnie usankcjonowana ani kulturowo określona, przez co same (choć przy aktywnym współudziale partnerek) wypracowują własną wizję bycia rodzicem (Mizielińska, 2017). Znajduje to odzwierciedlenie zarówno w decyzji o tym, jak dziecko ma zwracać się do obu kobiet (czy będą to dwie mamy, czy określenie „mama” zostanie zarezerwowane dla jednej z nich), jak i w wysiłkach podejmowanych przez matki społeczne w celu udowodnienia własnych wysokich kompetencji rodzicielskich (Bos, 2013). Wydaje się więc, że dla ukształtowania tożsamości rodzicielskiej w przypadku matek społecznych kluczowe jest uzyskanie rozpoznania społecznego, które pozwalałoby zminimalizować rozbieżność pomiędzy osobistą interpretacją własnych zachowań opiekuńczych (Z) oraz wytworzonym na tej podstawie obrazem siebie i własnej roli w rodzinie (J) a spostrzeganymi sygnałami płynącymi z otoczenia (I).

\section{Rodziny rekonstruowane}

Jak wskazuje Jean Lynch (2004), rekonstruowane rodziny dwóch kobiet wychowujących wspólnie dzieci zwykle powstają po rozstaniu się biologicznych rodziców i przejściu przez matkę etapu samodzielnej opieki nad dzieckiem. Jednocześnie autorka zwraca uwagę, że od momentu zaangażowania się w związek homoseksualny kobiety stosunkowo szybko decydują się zamieszkać razem (często w ciągu kilku miesięcy). W rodzinach tego typu procesy intrapsychiczne związane z rozwojem tożsamości są różne u matek 
biologicznych oraz u ich partnerek niemających wcześniej doświadczeń rodzicielskich, dlatego grupy te zostaną poniżej omówione odrębnie.

W badaniach Jessiki Morris, Kimberly Balsam i Esther Rothblum (2002) 44\% kobiet, które najpierw zdały sobie sprawę z tego, że są homoseksualne lub biseksualne, a dopiero potem zostały matkami, urodziło dziecko, będąc w związku lub małżeństwie z mężczyzną. Z kolei Fiona Tasker (2013) opisała grupę powodów wczesnego angażowania się w relacje heteroseksualne przez osoby, które później wychowywały dzieci w związkach jednopłciowych. Podawane przez nie motywy rozciągały się od chęci dostosowania się do wymogów społecznych i poddania presji partnera i rodziny, poprzez pragnienie realizowania się w roli rodzicielskiej oraz nadzieję, że małżeństwo pozwoli zażegnać homoseksualne inklinacje, po autentyczne uczucie do partnera i pragnienie budowania z nim rodziny. Doniesienia te sugerują więc, że niektóre kobiety wchodzą w związek z mężczyzną, jeszcze zanim proces rozwoju tożsamości orientacji seksualnej w ogóle się rozpocznie (nie mając wcześniej pragnień i doświadczeń homoseksualnych), inne zaś podejmują w ten sposób próbę utrzymania heteroseksualnego obrazu ja (J) i dostosowania do niego własnych zachowań (Z) tak, by były postrzegane jako oczekiwane i społecznie pożądane (I). Jak wskazują badania Lynch (2004), większość kobiet, wchodząc w związek z mężczyzną i decydując się na dziecko, doświadcza autentycznego zaangażowania i zwykle jest zaskoczona siłą późniejszych homoseksualnych pragnień. We wszystkich przypadkach ich intensyfikacja - oparta na realnej znajomości z drugą kobietą - prowadzi do zaangażowania się w związek i podjęcia decyzji o wspólnym życiu. Moment ten jest jednak poprzedzony wcześniejszym konstruowaniem tożsamości macierzyńskiej w oparciu o heteronormatywne wzorce.

Taka trajektoria rozwojowa pociąga za sobą specyficzne wyzwania tożsamościowe, odmienne od tych, którym stawiają czoła kobiety w rodzinach planowanych. Zaangażowanie w relację z kobietą aktywować może zinternalizowane wcześniej wyobrażenia i uprzedzenia dotyczące homoseksualności i jej niekorzystnego oddziaływania na rozwój dziecka. Ich skutkiem może być wewnętrzny konflikt między chęcią sprawowania jak najlepszej opieki nad dzieckiem a pragnieniem realizowania się w związku miłosnym. Rozbieżność pomiędzy dotychczasowym (heteroseksualnym) obrazem ja (J) a homoseksualnymi pragnieniami i zachowaniami (Z) może zachwiać wizerunkiem siebie jako dobrej matki (J) i implikować poczucie winy wobec dziecka (związane także z poczuciem odpowiedzialności za rozpad relacji heteroseksualnej). Z kolei obawy przed reakcjami innych i postrzeganie ich w kategoriach potencjalnych zagrożeń (I) - zarówno na poziomie instytucji 
(sąd, szkoła, służba zdrowia), jak i w bezpośrednich relacjach z bliskimi (dziećmi, ich ojcami i rodzinami pochodzenia) - może powstrzymywać kobietę przed ujawnianiem sytuacji rodzinnej. Życie w ukryciu pogłębiać zaś będzie rozbieżność między osobistym sposobem postrzegania siebie i własnego zachowania (J, Z) a tym, jak w percepcji jednostki widzą ją i oceniają inni (I). Wydaje się więc, że proces ten - przynajmniej przy dużym nasileniu uwewnętrznionych uprzedzeń - może pociągać za sobą silny niepokój i poczucie alienacji.

Jak jednak wynika z badań Lynch (2004) prowadzonych w rekonstruowanych rodzinach gejów i lesbijek, odkrywanie własnej homoseksualności jest w ich przypadku procesem stosunkowo krótkotrwałym, rzadko towarzyszą mu próby zaprzeczania, a pojawiające się w jego przebiegu negatywne emocje szybko tracą na intensywności i przemijają, prowadząc do włączenia i zaakceptowania homoseksualności jako istotnego elementu w obrazie ja. Wydaje się, że ważną rolę odgrywa tu właśnie ukształtowana wcześniej tożsamość rodzicielska i związana z nią konieczność sprostania opiekuńczym obowiązkom wobec dziecka, przy jednoczesnym podejmowaniu rozstrzygnięć dotyczących statusu dotychczasowej relacji małżeńskiej. Tym, co stanowi przedmiot niepokoju i troski rodziców w przypadku decyzji o życiu z osobą tej samej płci, jest raczej obawa przed społecznymi reakcjami, jakim muszą stawić czoła nie tylko oni sami, lecz także ich dzieci. Zaabsorbowanie rodziców sytuacją własnych dzieci i ich dobrostanem ujawnia się także w zarządzaniu poziomem jawności, który jest dostosowywany do możliwości adaptacyjnych dziecka i - o ile to możliwe - uzgadniany z nim (Lynch i Murray, 2000). Autorka badań w konkluzji wyraźnie sugeruje, że przebieg rozwoju tożsamości orientacji seksualnej w omawianej grupie ma charakter łagodniejszy w porównaniu z tym samym procesem u adolescentów, a także w porównaniu z tożsamościowymi dylematami, jakich doświadczają partnerzy i partnerki rodziców biologicznych. Wyrazistość i stabilność tożsamości macierzyńskiej, którym towarzyszy realne zaangażowanie w rolę, prawdopodobnie sprzyja zmniejszeniu wagi procesu rozwoju tożsamości orientacji seksualnej. Dzięki temu łatwiej uznać ją za element własnego ja bez nadawania jej wiodącego znaczenia w obszarze tożsamości złożonej.

Kobiety bezdzietne, wiążąc się z partnerkami posiadającymi potomstwo, zazwyczaj mają już wykształconą i zintegrowaną tożsamość orientacji seksualnej (Lynch, 2004). Kluczowym wyzwaniem tożsamościowym jest dla nich raczej odpowiedź na pytanie o to, kim są dla dziecka partnerki i kim są w nowej strukturze rodzinnej. W przeciwieństwie do osób funkcjonujących w roli macoch i ojczymów w rodzinach heteroseksualnych nie mogą 
skorzystać z gotowych rytuałów czy sposobów bycia przewidzianych dla par różnej płci. W języku brakuje też określeń służących oznaczeniu ich roli. Brak społecznego i prawnego rozpoznania ich związku czyni je dodatkowymi, „niewidzialnymi” towarzyszkami życia i opiekunkami dzieci, których nie planowały i które dopiero poznają w trakcie rozwijającej się relacji miłosnej (Lynch, 2000; Mizielińska, 2017). Potencjalnie okoliczności te sprzyjają więc powstaniu rozbieżności dotyczących tego, jak kobieta interpretuje swoją sytuację i charakter relacji z dzieckiem (Z) w świetle ukształtowanego wcześniej obrazu siebie jako osoby bezdzietnej (J) i wobec niejasnych, a niekiedy sprzecznych sygnałów płynących z otoczenia (I). Matka biologiczna może bowiem oczekiwać od swojej partnerki dzielenia codziennych obowiązków macierzyńskich, czyli de facto wejścia w rolę opiekunki/rodzica, równocześnie jednak ani instytucje (szkoła, służba zdrowia), ani inni członkowie rodziny (w tym ojciec dziecka) nie rozpoznają kobiety w podobny sposób, a niekiedy wręcz kwestionują jej prawo do zajmowania się dzieckiem. Ponadto wiele dodatkowych czynników, takich jak wiek dziecka i jego postawa wobec nowej osoby w rodzinie, stanowi istotny kontekst dokonywania przez kobietę samookreślenia i włączania kategorii „bycia rodzicem” (lub „bycia zastępczym rodzicem”) w obszar tożsamości złożonej.

\section{Podsumowanie}

Rodziny kobiet wychowujących wspólnie dzieci wpisują się w zróżnicowany krajobraz współczesnego życia rodzinnego w Europie i w Polsce. Ich istnienie podważa wiele tradycyjnych założeń dotyczących funkcjonowania rodziny, a nawet jej definiowania. Każe też zadawać pytania o przebieg indywidualnych procesów rozwoju tożsamości, której integracja traktowana jest jako istotny czynnik decydujący o psychicznym dobrostanie jednostki.

Przedstawiona w tekście koncepcja Vivienne Cass stanowi użyteczne narzędzie oglądu wyzwań tożsamościowych nie tylko w odniesieniu do adolescentów i młodych dorosłych osób homo- i biseksualnych (wobec których zwykle jest stosowana), lecz także w stosunku do osób nieheteroseksualnych podejmujących role rodzicielskie. Jak podkreśla autorka koncepcji, każde doświadczenie istotnej zmiany życiowej wymaga osobistego rozpoznania, interpretacji i włączenia nowych elementów do obrazu ja, przy czym proces ten odbywa się przy wykorzystaniu subiektywnego sposobu postrzegania informacji na swój temat płynących z otoczenia. Zmiana w strukturze rodziny czy decyzja o podjęciu roli rodzicielskiej, dla której nie ma usankcjonowania 
w prawie, niewątpliwie należą do tego typu doświadczeń. Odwołanie się do wprowadzonego przez Cass pojęcia interpersonalnej matrycy i rozbieżności między jej poszczególnymi elementami może ułatwić rozumienie procesów formowania tożsamości w takich okolicznościach. Aby jednak lepiej uchwycić ich przebieg, niezbędne wydaje się wyjście poza rozpatrywanie zmian w obrębie wybranej kategorii tożsamościowej (tożsamości orientacji seksualnej czy tożsamości macierzyńskiej) w kierunku uwzględnienia koegzystencji, wzajemnego oddziaływania i usytuowania względem siebie wielu (a przynajmniej wspomnianych dwóch) kategorii. Na ile są one wyodrębnione, wyraziste i osobiście istotne w złożonej tożsamości podmiotu? Czy pozostają w konflikcie, czy może funkcjonują niezależnie od siebie? Jak wysoko są przez jednostkę cenione? Jakie czynniki osobiste i środowiskowe mogą być pomocne w ich integracji? Pytania te wymagają wnikliwej eksploracji. Wyjściowo uprawnione wydaje się wyodrębnienie dwóch głównych zmiennych, które mają znaczenie dla przebiegu tej integracji: (1) czasowego następstwa rozwoju tożsamości orientacji seksualnej i tożsamości rodzicielskiej (pod tym względem różnią się rodziny planowane i rekonstruowane) oraz (2) sposobu powstania więzi z dzieckiem i jej specyfiki (inne wyzwania stoją przed matkami biologicznymi, inne przed społecznymi).

Na zakończenie warto podkreślić, że omawiane procesy trudno byłoby sprowadzić do jednego, standardowego wzorca. Kwestia zróżnicowania doświadczeń matek biologicznych i ich życiowych partnerek - matek społecznych jest zarówno w przypadku rodzin planowanych, jak i rekonstruowanych konieczna, choć niosąca ryzyko nieuprawnionej unifikacji indywidualnych doświadczeń. Różnorodność życia rodzinnego daleko wykracza poza przedstawione wyżej w dużym uproszczeniu dwa typy rodzin, a każda sytuacja wymaga specyficznego opracowania. Odrębnym, choć nie mniej ważnym zagadnieniem jest rozwój tożsamości u nieheteroseksualnych ojców, którzy - w porównaniu z kobietami - rzadziej wychowują dzieci w związkach jednopłciowych, są w mniejszym stopniu widoczni i - jako grupa badawcza - znacznie słabiej rozpoznani. Zastanawiające jest chociażby to, na ile ich doświadczenia w zakresie integrowania ojcowskich i nieheteroseksualnych aspektów tożsamości są podobne do doświadczeń kobiecych i jak bardzo kulturowe wzorce męskości determinują specyfikę tych procesów. Niezależnie od szczegółowych zagadnień wymagających podjęcia zarówno na gruncie refleksji teoretycznej, jak i pracy badawczej nie ulega wątpliwości, że lepsze rozpoznanie procesów tożsamościowych towarzyszących ludziom w ich życiu rodzinnym stanowi ważne zadanie, przed którym stoi współczesna psychologia, o ile chce nadążyć za zmianami społecznymi epoki postindustrialnej. 


\section{Literatura}

Backman, C. W. (1988). The Self: A Dialectical Approach. Advances in Experimental Social Psychology, 21, 229-260.

Bakiera, L. (2013). Zaangazowane rodzicielstwo a autokreacyjny aspekt rozwoju dorosłych. Warszawa: Difin.

Batory, A., Brygoła, E., Oleś, P. (2016). Odsłony tożsamości. Warszawa: Wydawnictwo Naukowe PWN.

Bojarska, K. (2008). Krytyka pojęcia orientacji seksualnej w świetle społecznego konstrukcjonizmu i teorii queer. W: A. Jodko (red.), Tabu seksuologii (ss. 11-31). Warszawa: Wydawnictwo Szkoły Wyższej Psychologii Społecznej „Academica”.

Bos, H. (2013). Lesbian Mother Families Formed Through Donor Insemination. W: A. E. Goldberg, K. R. Allen (red.), LGBT-Parent Families. Innovations in Research and Implications for Practice (ss. 21-38). New York: Springer.

Bowlby J. (1969), Attachment and Loss. Vol. 1. Attachment. New York: Basic Books.

Budrowska, B. (2000). Macierzyństwo jako punkt zwrotny w życiu kobiety. Wrocław: Fundacja na rzecz Nauki Polskiej.

Burkacka, I. (2018). Monoparentalność, wielorodzina i rodzina zrekonstruowana. Współczesne nazwy modeli życia rodzinnego. Artes Humanae, 2, 61-94.

Burke, P. J., Tully, J. C. (1977). The Measurement of Role Identity. Social Forces, 55 (4), 881-897.

Butler, J. (1990/2008). Uwikłani w płeć. Feminizm i polityka tożsamości. Warszawa: Wydawnictwo Krytyki Politycznej.

Cass, V. C. (1979). Homosexual Identity Formation: A Theoretical Model. Journal of Homosexuality, 4 (3), 219-234.

Cass, V. C. (1984a). Homosexual Identity: A Concept in Need of Definition. Journal of Homosexuality, 9 (2-3).

Cass, V. C. (1984b). Homosexual identity formation: Testing a theoretical model. Journal of Sex Research, 20, 143-167.

Cass, V. C. (1996). Sexual Orientation Identity Formation: A Western Phenomenon. W: R. Cabaj, T. Stein (red.), Textbook of Homosexuality and Mental Health (ss. 227-251). Washington: American Psychiatric Press.

Cass, V. C. (2015). A Quick Guide to the Cass Theory of Lesbian \& Gay Identity Formation. Ebook Edition. Bentley: Brightfire Press.

Coleman, E. (1982). Developmental Stages of the Coming Out Process. Journal of Homosexuality, 7 (2-3), 31-43.

Danna, D. (2011). Homoparentality in Italy: Myth of stigmatization. W: R. Kuhar, J. Takács (red.), Doing Families - Gay and Lesbian Family Practices (ss. 95-115). Ljubljana: Mirovni Inštitut.

DiLapi, E. M. (1989). Lesbian mothers and the motherhood hierarchy. Journal of Homosexuality, 18 (1-2),101-121.

Eliason, M. J., Schope, R. (2006). Shifting sands or solid foundation? Lesbian, gay, bisexual, and transgender identity formation. W: I. H. Meyer, M. E. Northridge (red.), 
Handbook of Lesbian, Gay, Bisexual, and Transgender Health (ss. 3-26). New York: Kluwer Academic/Plenum.

Erikson, E. (1950/2000). Dzieciństwo i społeczeństwo. Poznań: Dom Wydawniczy REBIS.

Gawlina, Z. (2003). Macierzyństwo jako wartość w kontekście przemian społecznych. Roczniki Socjologii Rodziny, 15, 33-46.

Giddens, A. (2006). Przemiany intymności: seksualność, miłość i erotyzm we współczesnych społeczeństwach. Warszawa: Wydawnictwo Naukowe PWN.

Glover, J. A., Galliher, R. V., Lamere, T. G. (2009). Identity Development and Exploration Among Sexual Minority Adolescents: Examination of a Multidimensional Model. Journal of Homosexuality, 56, 77-101.

ILGA Europe (2017). Rainbow Europe 2017 - Country Ranking, The International Lesbian, Gay, Bisexual, Trans and Intersex Association: https://rainbow-europe.org/countryranking, dostęp: 2.06.2018.

Inhinger-Tallman, M., Pasley, K., Buehler, C. (1993). Developing a Middle-Range Theory of Father Involvement Postdivorce. Journal of Family Issues, 14 (4), 550-571.

Jabłoński, D., Ostasz, L. (2001). Zarys wiedzy o rodzinie małżeństwie, kohabitacji i konkubinacie, perspektywa antropologii kulturowej i ogólnej. Olsztyn: Adiaphorn.

Kubera, J. (2013). Po postmodernizmie, czyli silne identyfikacje i słabe tożsamości. Nauka, $1,97-108$.

Lynch, J. M. (2000). Considerations of Family Structure and Gender Composition: The Lesbian and Gay Stepfamily. Journal of Homosexuality, 40 (2), 81-95.

Lynch, J. M. (2004). The Identity Transformation of Biological Parents in Lesbian/Gay Stepfamilies. Journal of Homosexuality, 47 (2), 91-107.

Lynch, J. M., Murray, K. (2000). For the Love of the Children: The Coming Out Process for Lesbian and Gay Parents and Stepparents. Journal of Homosexuality, 39 (1), 1-24.

MacPhee, D., Benson, J., Bullock, D. (1986). Influences on Maternal Self-Perceptions. Unpublished manuscript. Colorado State University. Google Scholar.

Marcia, J. E. (1980). Identity in Adolescence. W: J. Adelson (red.), Handbook of Adolescent Psychology (ss. 159-187). New York: Wiley.

Maurer, W. T., Pleck, J. H., Rane, T. R. (2001). Parental Identity and Reflected -Appraisals: Measurement and Gender Dynamics. Journal of Marriage and Family, May, 309-321.

McCarn, S. R., Fassinger, R. E. (1996). Revisioning Sexual Minority Identity Formation: A New Model of Lesbian Identity and Its Implications for Counseling and Research. Counseling Psychologist, 24, 508-534.

Miluska, J. (1996). Tożsamość kobiet i mężczyzn w cyklu życia. Poznań: Wydawnictwo Naukowe UAM.

Mizielińska, J. (2017). Odmienne czy zwyczajne? Rodziny z wyboru w Polsce. Warszawa: Wydawnictwo Naukowe PWN.

Mizielińska, J., Abramowicz, M., Stasińska, A. (2014). Rodziny z wyboru w Polsce. Życie rodzinne osób nieheteroseksualnych. Warszawa: Instytut Psychologii PAN.

Mizielińska, J., Struzik, J., Król, A. (2017). Różnym głosem. Rodziny z wyboru w Polsce. Warszawa: Wydawnictwo Naukowe PWN.

Morris, J. F., Balsam, K. F., Rothblum, E. D. (2002). Lesbian and Bisexual Mothers and Nonmothers: Demographics and the Coming-out Process. Journal of Family Psychology, 16 (2), 144-156. 
Oleś, P. (2008). O różnych rodzajach tożsamości oraz ich stałości i zmianie. W: P. Oleś, A. Batory (red.), Tożsamość i jej przemiany a kultura (ss. 41-84). Lublin: Wydawnictwo Katolickiego Uniwersytetu Lubelskiego.

Pilarska, A. (2012). Ja i tożsamość a dobrostan psychiczny. Poznań: Wydawnictwo Naukowe Wydziału Nauk Społecznych UAM.

Piotrowski, K. (2018). Adaptation of the Utrecht-Management of Identity Commitments Scale (U-MICS) to the measurement of the parental identity domain. Scandinavian Journal of Psychology, 59 (2), 157-166.

Secord, P. F., Backman, C. W. (1961). Personality Theory and the Problem of Stability and Change in Individual Behavior: An Interpersonal Approach. Psychological Review, 68 (1), 21-32.

Stelter, Ż. (2013). Petnienie ról rodzicielskich wobec dziecka niepełnosprawnego intelektualnie. Warszawa: Difin.

Stern, D. N. (1995). The Motherhood Constellation. New York: Basic Books.

Tasker, F. (2013). Lesbian and gay parenting postheterosexual divorce and separation. W: A. E. Goldberg, K. R. Allen (red.), LGBT-Parent Families. Innovations in Research and Implications for Practice (ss. 3-20). New York: Springer.

Tomalski, P. (2007). Nietypowe rodziny. O parach lesbijek i gejów oraz ich dzieciach z perspektywy teorii przywiq̨zania. Warszawa: Wydawnictwa Uniwersytetu Warszawskiego.

Ukleja, M. (2011). Procesy indywidualizacji i przemian tożsamościowych jako podstawa funkcjonowania „rodzin z wyboru”. W: M. Świątkiewicz-Mośna (red.), Rodzina. Kondycja i przemiany (ss. 56-74). Kraków: Wydawnictwo Uniwersytetu Jagiellońskiego.

Ukleja, M. (2014). Rodziny z wyboru. Homoseksualny związek jako współczesna alternatywa rodziny - analiza zjawiska. Acta Universitatis Lodziensis. Folia Sociologica, 51, 117-133.

Walsh, F. (1996). The concept of family resilience: Crisis and challenge. Family Process, 35, 261-281.

Winnicott, D. (1953). Transitional objects and transitional phenomena. International Journal of Psychoanalysis, 34, 89-97.

Worthington, R. L., Savoy, H. B., Dillon, F. R., Vernaglia, E. R. (2002). Heterosexual Identity Development: A Multidimensional Model of Individual and Social Identity. The Counseling Psychologist, 30, 4, 496-531. 